\title{
Effects of chronic heat exposure and protein intake on growth performance, nitrogen retention and muscle development in broiler chickens
}

\author{
Soraya Temim, Anne-Marie Chagneau, Solange Guillaumin, \\ Joël Michel, Rosa Peresson, Pierre-André Geraert, \\ Sophie Tesseraud*
}

Station de recherches avicoles, Inra, 37380 Nouzilly, France

(Received 12 December 1997; accepted 2 September 1998)

\begin{abstract}
The respective effects of ambient temperature, dietary crude protein and feed intake were investigated in finishing chickens and the consequence of protein supplementation under high temperature conditions was analysed in particular. Heat-related reduction in growth was associated with decreased nitrogen retention ( -30 or $-35 \%$ according to the diet), which could not be explained by the observed lower feed intake alone. Tissue samples performed in 5- to 6-week-old chicks showed varying effects of heat according to the muscles studied: at $32{ }^{\circ} \mathrm{C}$, the proportion of Pectoralis major muscle (in percentage of body weight) appeared slightly reduced (reduction lower than $10 \%$ ), whereas the proportion of two leg muscles were increased $(+10$ to $+15 \%$ for the Sartorius muscle; $+5 \%$ for the gastrocnemius muscle). At $32^{\circ} \mathrm{C}$, providing a high protein diet significantly $(P<0.05)$ increased weight gain and feed efficiency, and slightly improved whole body protein deposition. (C) Inra/Elsevier, Paris.
\end{abstract}

chronic heat exposure / dietary protein level / growth / nitrogen retention / muscle

Résumé - Influence de l'exposition chronique à la chaleur et de l'ingéré protéique sur les performances de croissance, la rétention azotée et le développement musculaire chez le poulet de chair. Nous avons étudié les effets respectifs de la température ambiante, du taux protéique du régime et de l'ingéré chez des poulets en finition et analysé en particulier l'incidence d'une supplémentation protéique lors de l'exposition à des températures élevées. La réduction de la croissance au chaud est associée à une diminution de la rétention azotée ( -30 ou $-35 \%$ selon le régime) qui ne s'explique pas seulement par la baisse d'ingéré observée. Des prélèvements de tissus réalisés à 5-6 semaines montrent des effets différents de la chaleur selon les muscles : à $32^{\circ} \mathrm{C}$, la proportion de muscle Pectoralis major (en \% du poids vif) apparaît légèrement réduite (réduction inférieure à

* Correspondence and reprints

E-mail: tesserau@tours.inra.fr 
$10 \%)$ alors que celles de deux muscles de la patte sont augmentées (+ 10 à $15 \%$ pour le Sartorius $;+5 \%$ pour le Gastrocnemius). A $32{ }^{\circ} \mathrm{C}$, la distribution du régime riche en protéines entraîne une augmentation significative $(p<0,05)$ du gain de poids et de l'efficacité alimentaire, et une légère amélioration du dépôt protéique corporel. (C) Inra/Elsevier, Paris.

exposition à la chaleur / taux protéique du régime / croissance / rétention azotée / muscle

\section{INTRODUCTION}

High ambient temperatures induce economic losses for the poultry industry both in hot countries and in regions with a temperate climate such as France: 40 million francs are lost per year during the summer [6]. Heat exposure decreases feed consumption in order to reduce metabolic heat production and maintain homeothermy, and also leads to a lower weight gain $[3,8,13,17]$. Compared with pair-fed birds exposed to thermoneutrality, heat-exposed chickens still exhibit slower growth and decreased feed efficiency $[14,15]$.

The impact of heat exposure can be reduced by controlling environmental factors (house temperature and ventilation) or by breeding techniques such as fasting, water control and limited poultry density in the building. However, alternative strategies involving feeding need to be considered to improve chicken growth in hot environments, e.g. dietary supplementation with electrolytes or ascorbic acid, and modifications of dietary composition $[3,5,10,21$, 24 ]. Another solution also consists in increasing dietary crude protein in order to limit the reduction in protein intake under heat stress conditions.

This strategy has been controversial since protein usually contributes more to the heat increment than carbohydrates or fat. Some authors have suggested minimising protein levels and improving the balance of amino acids by adding synthetic essential amino acids $[3,30,31]$. However, whereas the negative effect of excess protein is incontestable at thermoneutrality, increasing the dietary protein level at $32{ }^{\circ} \mathrm{C}$ decreases the heat increment [14]. Moreover, providing high protein diets can improve chicken growth in hot environments $[7,20]$. We therefore studied the effect of chronic heat exposure $\left(32\right.$ versus $22^{\circ} \mathrm{C}$ ) and dietary crude protein ( 25 versus $20 \%$ ) on body and muscle growth of broiler chickens between 4 and 6 weeks of age. We also investigated the influence of decreased feed intake at both 22 and $32{ }^{\circ} \mathrm{C}$.

\section{MATERIALS AND METHODS}

\subsection{Birds and experimental design}

Day-old ISA JV15 male broiler chicks $(n=350)$ from a local hatchery (Sicamen, Bouloire, France) were reared in individual battery cages in controlled environment rooms. Water was available ad libitum. Up to 28 days of age, they received a complete starter diet of the following composition $\left(\mathrm{g} \cdot \mathrm{kg}^{-1}\right)$ : maize 485 , wheat 126 , soyabean meal 220 , meat meal 41 , fat 40 , maize gluten 50 , dicalcium phosphate 12.7 , calcium carbonate 12.4 , sodium chloride 4 , L-lysine 2.0 , DL-methionine 0.9 , vitamins and minerals 6. The $23 \mathrm{~h} / 1 \mathrm{~h}$ light/dark cycle lighting program was maintained until the end of the experiment. The ambient temperature was gradually decreased from $32^{\circ} \mathrm{C}$ when the birds were 1 day old to $22{ }^{\circ} \mathrm{C}$ when they were 4 weeks old. At 4 weeks of age, birds were fasted for $4 \mathrm{~h}$, weighed, and then 216 of them were selected in order to form six groups of similar weights $(1165 \pm 12 \mathrm{~g}$ ). They were placed in individual battery cages in controlled environment rooms maintained at a constant temperature of either 32 or $22^{\circ} \mathrm{C}$ and relative humidity was maintained at about $55 \%$. Birds were fed either a control diet (C) or a high protein diet (HP) from 4 to 6 weeks of age (table I). The analysed protein contents were 19.6 and 
Table I. Composition of experimental control (C) and high protein (HP) diets $\left(\mathrm{g} \cdot \mathrm{kg}^{-1}\right)$.

\begin{tabular}{lcc}
\hline & C Diet & HP Diet \\
\hline Ingredients and analysis & & \\
Maize & 624.0 & 240.0 \\
Corn gluten meal $(60 \% \mathrm{CP})$ & 17.5 & 12.0 \\
Wheat & 278.0 & 294.3 \\
Soyabean meal $(48 \% \mathrm{CP})$ & & 296.7 \\
Soyabean protein & 38.4 & 65.0 \\
Rapeseed oil & 11.6 & 50.0 \\
Calcium carbonate & 19.4 & 11.7 \\
Dicalcium phosphate & 4.0 & 19.3 \\
Salt & 1.0 & 4.0 \\
Trace mineral ${ }^{1}$ & 5.0 & 1.0 \\
Vitamins & 0.8 & 5.0 \\
DL-methionine & 0.3 & 1.0 \\
Lysine-HCL & & \\
& & \\
Calculated analysis & 100 & 3090 \\
Metabolisable energy $\left(\mathrm{kcal} \cdot \mathrm{kg}^{-1}\right)$ & 196 & 251 \\
Crude protein & 70 & 73 \\
Crude fat & 10.1 & 13.8 \\
Lysine & 7.6 & 9.5 \\
Sulphur amino acids & 7.4 & 9.3 \\
Threonine & 10.0 & 12.8 \\
Valine & 2.2 & 3.1 \\
Tryptophan & 18.7 & 20.9 \\
Leucine & 9.1 & 12.2 \\
Isoleucine & & \\
\hline
\end{tabular}

${ }^{1}$ See Tesseraud et al. $[27,29]$.

$24.7 \%$ in C and HP diets, respectively. All the diets were isoenergetic, in pellet form $(2.5 \mathrm{~mm}$ in diameter) and had the same proportions of amino acids in relation to lysine content. At both rearing temperatures, the control diet (C) was given either ad libitum (AL groups) or at a restricted feed intake rate (RF groups) corresponding to $80 \%$ of ad libitum intake.

\subsection{Measurements}

Daily feed intake was individually measured at 0900 hours each morning. Figure 1 shows the actual values for food intake. Note that relatively similar amounts of feed were consumed in the $\mathrm{RF}$ group fed the $\mathrm{C}$ diet and exposed to $22^{\circ} \mathrm{C}$ and in the AL group fed the HP diet and exposed to $32{ }^{\circ} \mathrm{C}$. Growth performance was determined during the experimental period ( 28 to 42 days of age). Body weights were recorded after a $4-\mathrm{h}$ period without feed ( $n=25-30$ for $\mathrm{AL}$ groups and $n=18$ for RF groups).

Nitrogen retention, i.e. whole body protein deposition, was estimated in 7-8 chickens per treatment at 5.5 weeks of age by the difference between nitrogen intake and excretion over a 2-day period (between 38 and 40 days of age). The chickens selected displayed growth performance similar to the mean of the group. Excreta were collected, weighed and freeze-dried. Nitrogen contents of diet and excreta were measured by the Kjeldahl procedure.

Finally, between 5 and 6 weeks of age, 14 (in AL groups) and 9-10 (in RF groups) birds were killed after pentothal injection and exsanguinated. These chickens displayed growth performances similar to the mean of their group. Three types of skeletal muscles were chosen on the basis of their histochemical properties: the Pectoralis major (a breast muscle, entirely fast-twitch glycolytic fibre type), the Sartorius and the Gastrocnemius 


\section{Feed intake $(g / d)$}

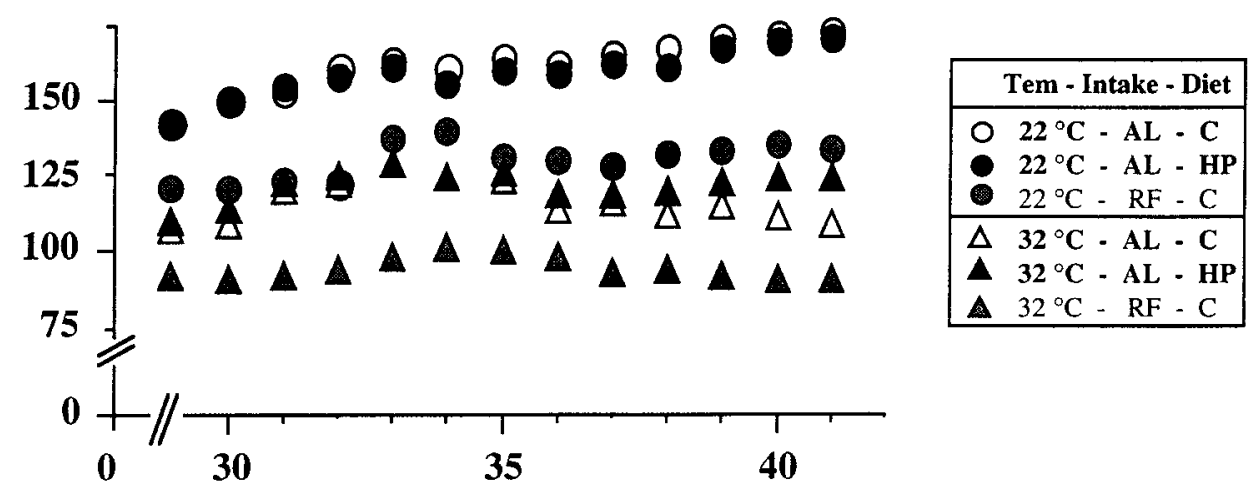

Age (d)

Figure 1. Daily feed intake of male chickens exposed to 22 or $32{ }^{\circ} \mathrm{C}$ and fed a control diet (C) or a high-protein diet (HP) from 4 to 6 weeks of age. Values are means. For details of diets and procedures, see table $I$ and Materials and methods section. AL, ad libitum; RF, restricted feed; Tem, temperature.

(two leg muscles, mixed-fibre type) muscles. The left Pectoralis major, Sartorius and Gastrocnemius muscles were excised, weighed, frozen in liquid nitrogen and finally stored at $-20^{\circ} \mathrm{C}$ until analysis. Frozen muscles were finely ground in liquid nitrogen and the procedures were performed as described previously [27-29]. Tissue protein content was measured according to Smith et al. [26] by the colorimetric reaction with bicinchroninic acid (Pierce, Rockford, USA). Tissue RNA content was measured on the basis of the ultraviolet (UV) absorbance at $260 \mathrm{~nm}$, with a correction for peptide material based on the UV absorbance at $232 \mathrm{~nm}$, as described by Munro and Fleck [23]. The ribosomal capacity, i.e. the capacity for protein synthesis, was estimated as the ratio of RNA to protein $[28,29]$.

\subsection{Statistical analysis}

Values are given as means with their standard errors (SE). SE often differed between the six groups since feed restriction reduced variability and high temperature increased it. Due to the heterogeneity of variance between treatments (determined by the Bartlett test), data were analysed using the Kruskal-Wallis non-parametric test [19] and means were compared by the Mann-
Whitney U test (see Materials and methods sections of $[1,2,15])$. This heterogeneity was not observed for muscle proportions and ribosomal capacities; these findings were analysed using a classical variance analysis procedure (parametric test). Three-way ANOVA was performed to discriminate between the effects of temperature, diet and intake level, and their interactions.

\section{RESULTS}

\subsection{Growth performance}

At $22^{\circ} \mathrm{C}$, 6-week body weights were $2389 \pm 31$ and $2421 \pm 28 \mathrm{~g}$ for AL groups fed C and HP diets, respectively, and 2069 $\pm 18 \mathrm{~g}$ for the RF group fed the C diet. At $32{ }^{\circ} \mathrm{C}$, they were $1821 \pm 27$ and $1925 \pm$ $34 \mathrm{~g}$ for AL groups fed C and HP diets, respectively, and $1708 \pm 16 \mathrm{~g}$ for the $\mathrm{RF}$ group fed the $\mathrm{C}$ diet. Average values for feed intake, weight gain and feed conversion ratio (grams of feed per gram of gain) are presented in figure 2. Chronic heat exposure significantly decreased feed intake and weight gain $(P<0.001)$ : for feed intake, -29 and $-23 \%$ with $C$ and HP diets, respec- 


\section{Feed intake ( $g / d)$}

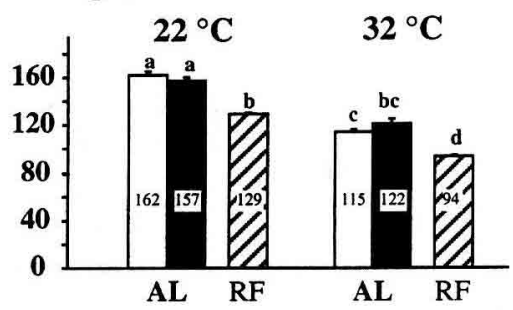

Weight gain (g/d)
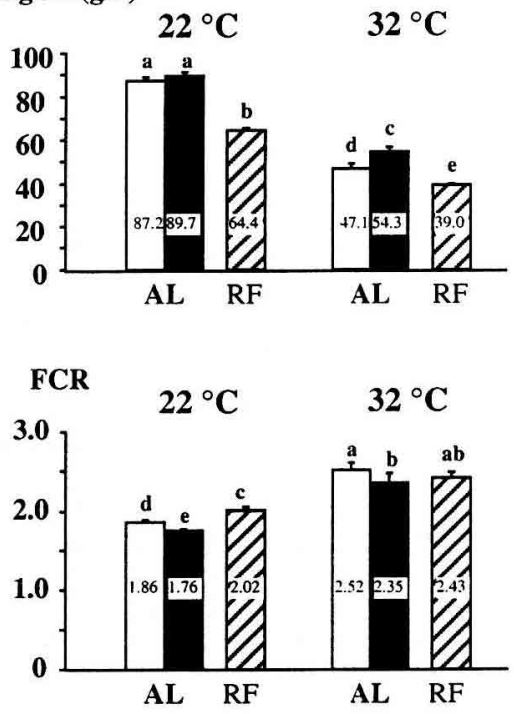

Figure 2. Feed intake, weight gain and feed conversion ratio (FCR) of male chickens exposed to 22 or $32{ }^{\circ} \mathrm{C}$ and fed a control diet (C) ( $\square \square$ ) or a high-protein diet (HP) ( $\square$ ) from 4 to 6 weeks of age. Values are means $\pm \operatorname{SE}(n=25-30$ for AL groups; $n=18$ for RF groups); means within parameter with no common letter differ significantly $(P<0.05)$; AL, ad libitum; $\mathrm{RF}$, restricted feed.

tively; for weight gain, -46 and $-39 \%$, respectively. Since weight gain was more reduced than feed intake, the feed conversion ratio was increased under high temperatures $(P<0.001)$ (approximately $+35 \%$ irrespective of diet).

Feed restriction by about $20 \%$, irrespective of diet, significantly decreased weight gain: -26 and $-17 \%$ at 22 and $32{ }^{\circ} \mathrm{C}$, respectively. The feed conversion ratio was thus increased at $22^{\circ} \mathrm{C}(+9 \%, P<0.05)$, whereas it was unchanged at $32{ }^{\circ} \mathrm{C}(-4 \%$, $P=0.50)$.

The HP diet did not significantly alter feed intake at the two ambient temperatures (figure 2). Note, however, that even though there was no effect of protein level on feed intake at $22^{\circ} \mathrm{C}$, the HP diet increased feed intake in the second week at $32^{\circ} \mathrm{C}$ (figure I). It increased weight gain at $32{ }^{\circ} \mathrm{C}(+15 \%$, $P<0.05)$ but there was no change at $22^{\circ} \mathrm{C}$ (variation lower than $5 \%, P=0.38$ ). Finally, it resulted in significantly reduced feed conversion ratios $\left(-5\right.$ and $-7 \%$ at 22 and $32{ }^{\circ} \mathrm{C}$, respectively; $P<0.05$ ).

\subsection{Nitrogen balance}

Irrespective of diet, heat exposure decreased nitrogen intake expressed both in $\mathrm{g} / \mathrm{d}$ (approximately $-27 \%, P<0.01)$ and in $\mathrm{g} / \mathrm{d}$ per kg BW (about $-13 \%, P<0.05$ ) (table II). In contrast, it did not modify nitrogen excretion $(P>0.05)$ and, as a result, it very significantly reduced nitrogen retention $(P<0.01):-47$ and $-40 \%$ with $C$ and $\mathrm{HP}$ diets, respectively, when expressed in $\mathrm{g} / \mathrm{d}$; -37 and $-29 \%$, respectively, when expressed in $\mathrm{g} / \mathrm{d}$ per $\mathrm{kg} \mathrm{BW}$.

Irrespective of ambient temperature, feed restriction decreased nitrogen intake by approximately $20 \%$ when expressed in g/d or by $10-15 \%$ when expressed in $\mathrm{g} / \mathrm{d}$ per $\mathrm{kg} \mathrm{BW}$. It also reduced nitrogen excretion, mainly under high temperatures, with reductions of 30 to $35 \%$ depending on the mode of expression ( $\mathrm{g} / \mathrm{d}$ or $\mathrm{g} / \mathrm{d}$ per $\mathrm{kg} \mathrm{BW}$ ). It therefore resulted in significantly decreased nitrogen retention at $22{ }^{\circ} \mathrm{C}(-10$ to $-20 \%$ depending on the mode of expression) without any clear modification at $32{ }^{\circ} \mathrm{C}$ (variations lower than $10 \%, P>0.20$ ). Note that the chickens exposed to $32{ }^{\circ} \mathrm{C}$ and fed the $\mathrm{C}$ diet had lower nitrogen retention than the feed-restricted chickens kept at thermoneu- 


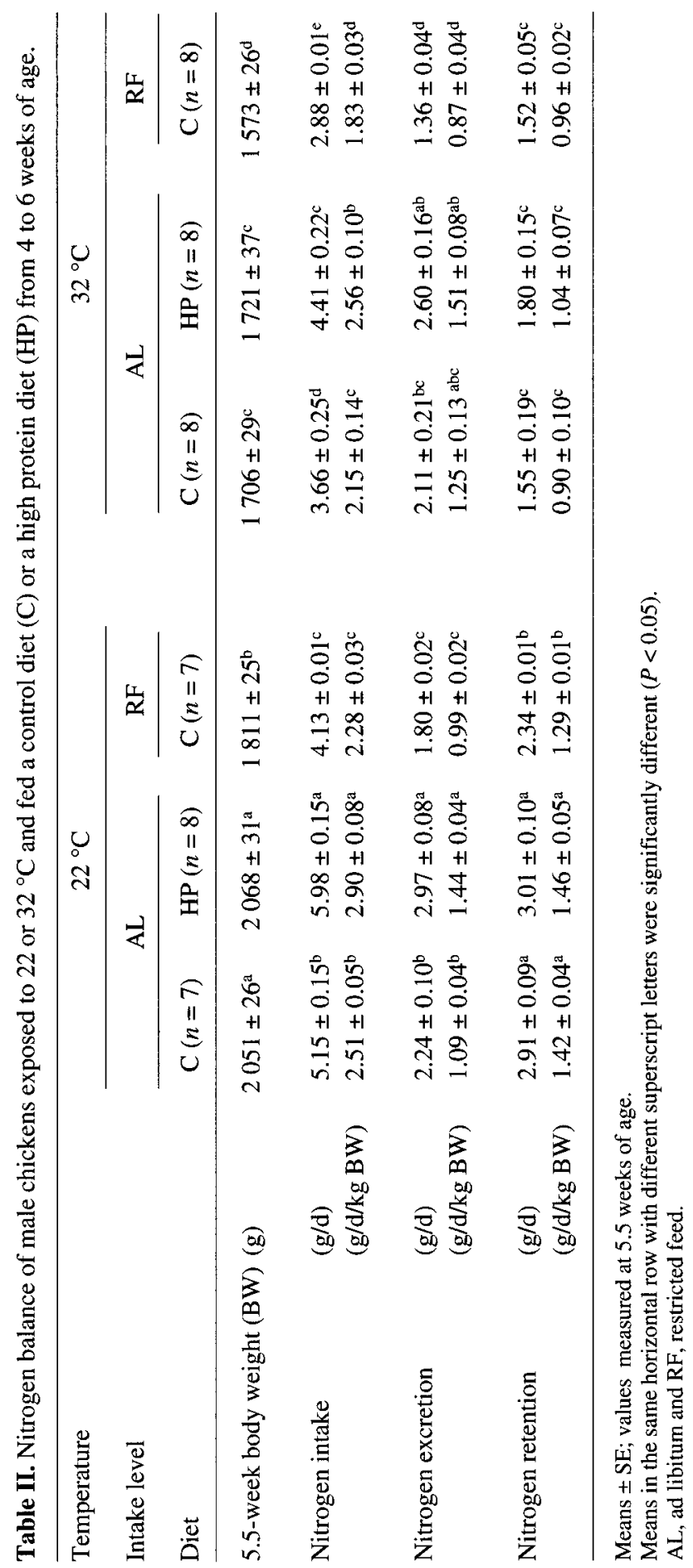


trality $(-30 \%, P<0.05)$, although nitrogen intake, expressed in $\mathrm{g} / \mathrm{d}$ per $\mathrm{BW}$, did not significantly differ between these two groups $(P=0.86)$. This suggests that the heatrelated reduction in nitrogen retention could not be explained by decreased feed intake under hot conditions.

The HP diet increased nitrogen intake ( +15 to $+20 \%$ according to the ambient temperature) and nitrogen excretion $(+20$ to $+30 \%$ ) whatever the mode of expression ( $\mathrm{g} / \mathrm{d}$ or $\mathrm{g} / \mathrm{d}$ per $\mathrm{kg} \mathrm{BW}$ ). Nitrogen retention was not changed at $22^{\circ} \mathrm{C}$ (only $+3 \%$ of variation), whereas it was increased at $32{ }^{\circ} \mathrm{C}$ $(+16 \%)$; however, this diet-related difference did not reach statistical significance.

\subsection{Muscle characteristics}

Muscle weights, protein and RNA contents are presented in table III. They were decreased by chronic heat exposure $(P<0.01)$ and slightly increased by the HP $\operatorname{diet}(P>0.05)$. Muscle proportions and ribosomal capacities are presented in figure 3. High temperatures slightly decreased the proportion of $\mathrm{PeC}$ toralis major muscle (reduction lower than $10 \%, P=0.06$ ), whereas the proportions of the two leg muscles were significantly increased (about +10 to $15 \%$ for the Sartorius muscle, $+5 \%$ for the Gastrocnemius muscle). Three-way ANOVA showed a significant effect of the intake level (i.e. feed restriction) only for the sartorius muscle ( $P>0.25$ for the other muscles). It showed a diet effect $(P<0.05)$ on Gastrocnemius muscle proportions. There was only a tendency to a diet effect or no effect at all for the two other muscle proportions. Finally, in terms of ribosomal capacity $(\mathrm{Cs})$, there was no significant effect of diet or intake level, irrespective of muscle. Conversely, there was a very significant ambient temperature effect $(P<0.001)$ and heat-exposed chickens had lower $C$ s than birds kept at thermoneutrality, irrespective of diet or intake level. It is of note that the interactions between diet and temperature and between temperature and intake level were not significant for $\mathrm{Cs}$ or muscle proportion, irrespective of muscles studied.

\section{DISCUSSION}

As reported in the literature, heat-exposed chickens showed decreased growth $[3,8$, $13,17]$. Moreover, the reduction in growth was greater than the reduction in feed intake, resulting in increased feed to gain ratio, in agreement with previous data $[1,15,17]$. Chronic heat exposure appears therefore to have a depressive effect which is independent of the decrease in feed intake. A similar conclusion has been drawn comparing chickens reared at 22 and $32{ }^{\circ} \mathrm{C}$ and receiving the same feed intake $[14,15]$. Conversely, in rats and piglets an improvement in feed efficiency was observed at high temperatures $[9,25]$. We also showed that heat reduced nitrogen retention, this effect being independent of feed intake. According to Geraert et al. [15], chronic exposure to $32^{\circ} \mathrm{C}$ also decreases protein gain $(-54 \%)$ and protein retention efficiency $(-46 \%)$.

Under high environmental temperatures, chickens had a slightly lower proportion of Pectoralis major muscle $(P=0.06)$, whereas the proportion of the two leg muscles was significantly increased $(P<0.001$ for the Sartorius muscle and $P<0.05$ for the Gastrocnemius muscle). Howlider and Rose [18] similarly found a reduced breast meat yield. These results are also in agreement with those of Aïn Baziz et al. [1] who observed a decreased proportion of breast muscle $(-12 \%)$ and a slight but significant increase in the proportion of leg muscles, i.e. thigh plus drumstick proportion $(+6 \%)$. Note that the heat-related modifications of proportion of muscle could not be explained by a lower feed intake since there was either no effect of feed intake level $(P=0.43$ for the Pectoralis major muscle and $P=0.29$ for the Gastrocnemius muscle) or an opposite effect between heat exposure and feed intake for the Sartorius muscle. Indeed, as 


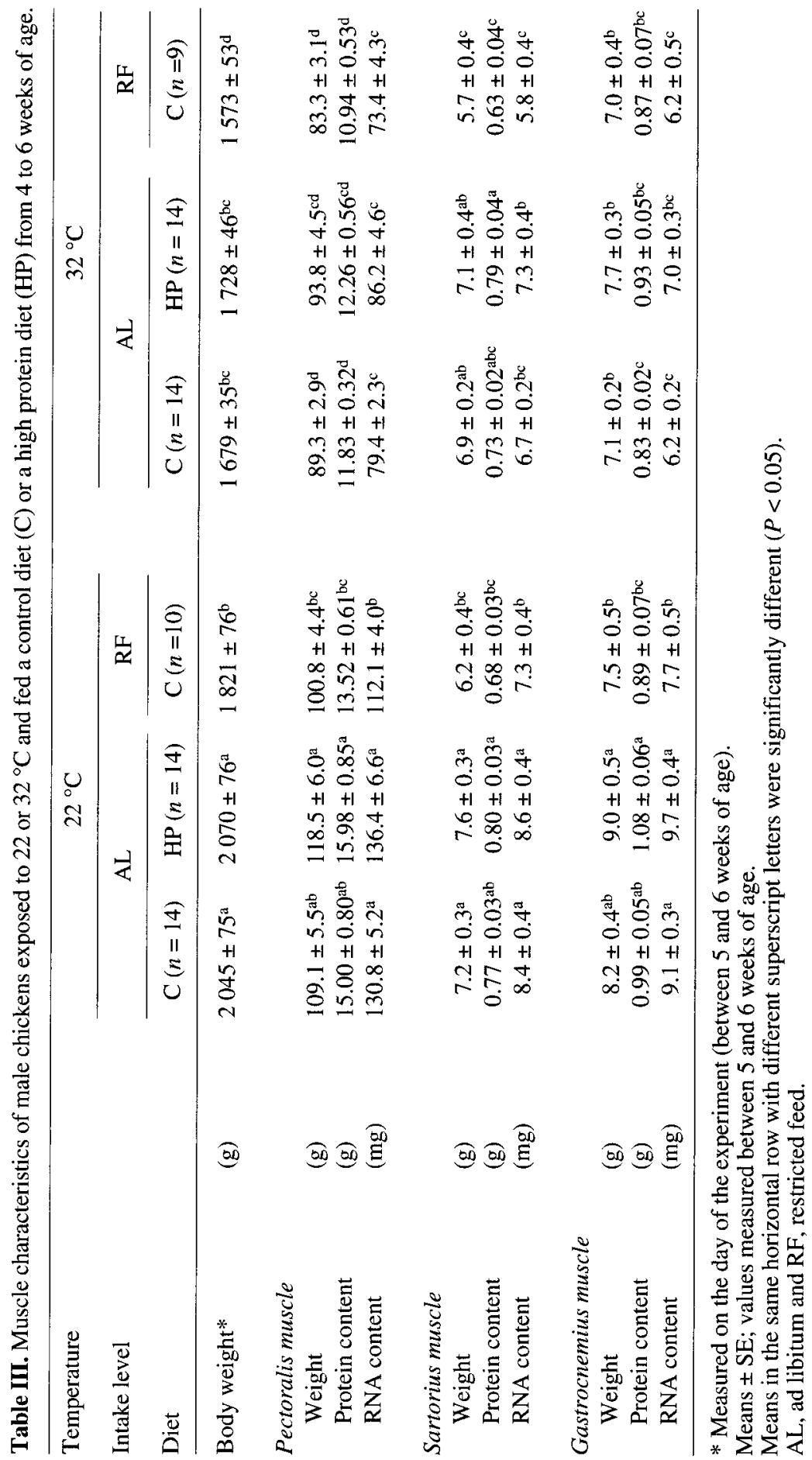


Weight $(\mathrm{g} / 100 \mathrm{~g} \mathrm{BW})$

$22^{\circ} \mathrm{C}$

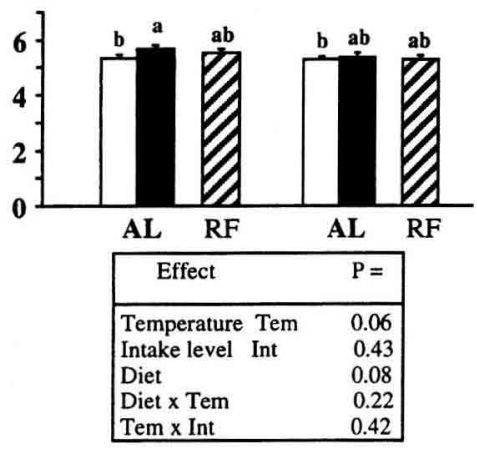

$22^{\circ} \mathrm{C}$

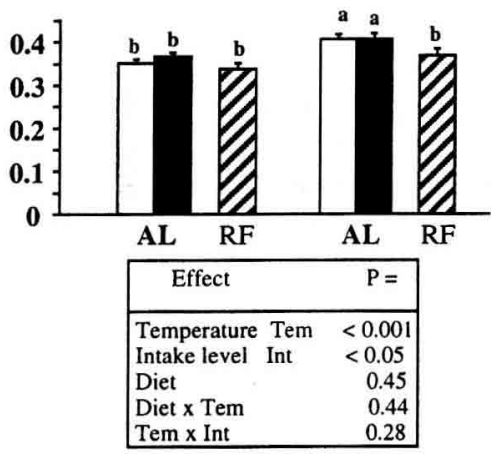

$22^{\circ} \mathrm{C}$

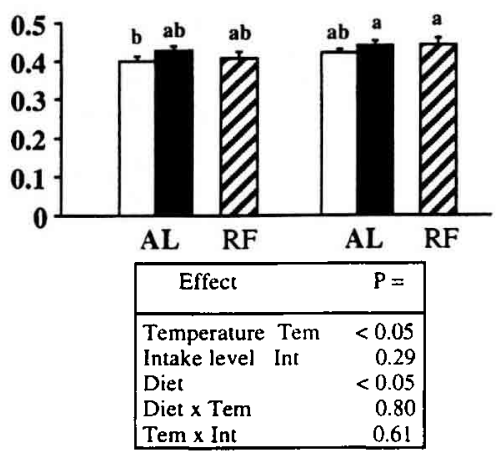

Cs $(\mathrm{mg} / \mathrm{g})$

$22{ }^{\circ} \mathrm{C}$

$32{ }^{\circ} \mathrm{C}$

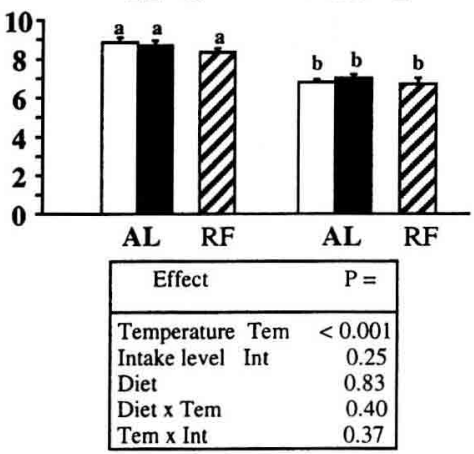

$22^{\circ} \mathrm{C}$

$32{ }^{\circ} \mathrm{C}$

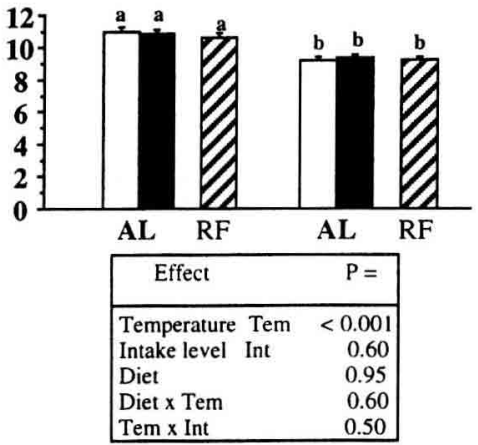

$22{ }^{\circ} \mathrm{C}$

$32{ }^{\circ} \mathrm{C}$

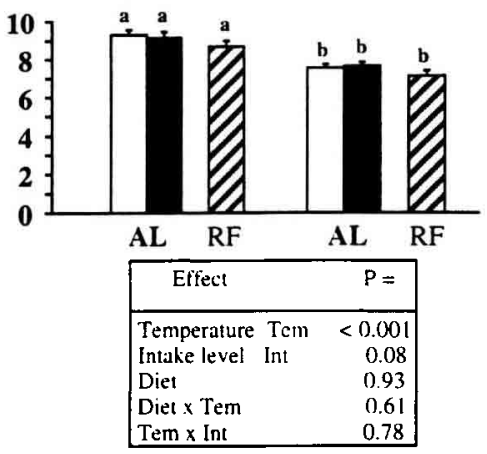

Pectoralis major

\section{Sartorius}

Gastrocnemius

Figure 3. Muscle proportions and ribosomal capacities (Cs) of male chickens exposed to 22 or $32{ }^{\circ} \mathrm{C}$ and fed a control diet (C) $(\square \square /$ ) or a high-protein diet (HP) ( $\square$ ) from 4 to 6 weeks of age. Values are means $\pm \mathrm{SE}$ ( $n=14$ for AL groups; $n=9-10$ for RF groups); measurements performed between 5 and 6 weeks of age; means within parameter with no common letter differ significantly $(P<0.05)$; $\mathrm{AL}$, ad libitum; RF, restricted feed; BW, body weight. Tables summarise results of statistical analysis (three-way ANOVA). 
for sartorius muscle proportions, there was a significant reduction $(P<0.05)$ with a lower feed intake and conversely a significant increase $(P<0.001)$ induced by high temperatures. In the present experiment, the Pectoralis major muscle was the most sensitive to high temperatures. The differential response to heat exposure in individual muscles could be characteristic of the fibre type composition of that muscle. The response of the Pectoralis major muscle, which is an entirely fast-twitch glycolytic fibre type muscle, is greater to nutritional factors such as lysine deficiency than the mixed fibre type Sartorius muscle [27]. In particular, differences might be related to the energy characteristics of these muscles and thus to their respective substrates: glucose and fatty acids.

We found a direct effect of heat exposure on muscle Cs. At high temperatures, the reduced capacity for protein synthesis represented changes in protein metabolism which could explain reduced gain in muscle protein and therefore in muscle development. Further investigations of muscle protein metabolism, including the measurement of in vivo protein synthesis by an appropriate technique, e.g. the flooding dose method developed by Garlick et al. [12] and the determination of proteolysis, need to be undertaken to provide a better understanding of the regulation of muscle protein deposition.

In the present study, the HP diet appeared to be beneficial at $32{ }^{\circ} \mathrm{C}$ since it reduced the adverse effects of high temperatures on growth and feed efficiency. This is in agreement with results obtained by Kubena et al. [20]. This effect might, however, be dependent on the genotype since birds with different growth rates and fatness respond differently to dietary protein level under heat stress [7]. In suggesting a positive effect of a high protein diet in hot conditions, our results contradict the idea that lowering dietary protein content with suitable supplementation with essential amino acids represents a way to improve chicken perfor- mance in this stress situation $[3,30,31]$. On the contrary, recent findings have shown that providing a low protein diet $16 \%$ crude protein with added lysine, methionine, threonine, arginine and valine versus $20 \%$ ) does not prevent a negative heat effect, and it even worsens performance [2].

The enhanced growth due to the high protein diet was not related to an increase in feed intake in hot conditions. Note, however, that the HP diet did not reduce feed intake at $32{ }^{\circ} \mathrm{C}$, whereas metabolic heat production could be increased, subsequently limiting feed consumption. In fact, while heat production expressed as a proportion of $\mathrm{ME}$ intake was increased by higher dietary protein content (23 versus $19 \%$ crude protein) at $22^{\circ} \mathrm{C}$, it was depressed by a high protein diet at $32^{\circ} \mathrm{C}$ [14]. This result observed in experimental lines is consistent with the findings of a previous study by McLeod [22] in broilers.

In the present study, increasing dietary protein content in hot conditions limited the heat-related reduction in protein intake: $30.1 \mathrm{~g}$ protein per day at $32{ }^{\circ} \mathrm{C}$ with the HP diet compared to $22.5 \mathrm{~g}$ protein per day at $32{ }^{\circ} \mathrm{C}$ with the $\mathrm{C}$ diet, the value at $22{ }^{\circ} \mathrm{C}$ with the $C$ diet being equal to $31.8 \mathrm{~g}$ protein per day. Chick growth became better despite remaining lower than that recorded at thermoneutrality. Note that our results did not allow determination of protein requirement under chronic heat exposure. This requires further investigation. Moreover, several authors have suggested that requirements in some amino acids other than lysine and methionine can be increased by high temperatures $[2$, $4,5,11,16]$.

In conclusion, our results indicate that it is possible to limit the adverse effects of high ambient temperatures using high protein diets. The poorly understood mechanisms that regulate chicken metabolism under heat exposure need to be elucidated in order to provide a basis for diet formulation (protein requirement and amino acid supplementation) and to better adapt nutrition to high environmental temperatures. 


\section{ACKNOWLEDGMENTS}

The work was funded by SYPRAM (France), an association created by the 'Association pour le maintien de l'élevage en Bretagne', the 'Syndicat National des Industriels de la Nutrition Animale' and the 'Syndicat des coopératives d'Aliments Composés'. We would like to thank K. Gerard for animal care. We are also grateful to D. Raine for help in preparing the English version of the manuscript.

\section{REFERENCES}

[1] Aïn Baziz H., Geraert P.A., Padilha J.C.F., Guillaumin $\mathrm{S}$., Chronic heat exposure enhances fat deposition and modifies muscle and fat partition in broiler carcasses, Poult. Sci. 75 (1996) 505-513.

[2] Alleman F., Leclercq B., Effect of dietary protein and environmental temperature on growth performances and water consumption of male broiler chickens, Br. Poult. Sci. 38 (1997) 607-610.

[3] Austic R.E., Feeding poultry in hot and cold climates, in: Youssef M.K. (Ed.), Stress Physiology in Livestock, CRC Press, 1985, pp. 123-136.

[4] Balnave D., Nutritional strategies for alleviating the adverse effects of heat stress, in: Proceedings of the XXth World Poultry Congress WPSA, New-Delhi, India, 2-5 September 1996, pp. 185-194.

[5] Balnave D., Oliva A., Responses of finishing broilers at high temperatures to dietary methionine source and supplementation levels, Aust. J. Agric. Res. 41 (1990) 557-567.

[6] Bouvarel I., Franck Y., Importance des coups de chaleur et des baisses de performances en été en aviculture, Sci. Technol. Avicoles 8 (1994) 7-8.

[7] Cahaner A., Pinchasov Y., Nir I., Nitsan Z., Effects of dietary protein under high ambient temperature on body weight, breast meat yield, and abdominal fat deposition of broiler stocks differing in growth rate and fatness, Poult. Sci. 74 (1995) 968-975.

[8] Charles D.R., Temperature for broilers, World's Poult. Sci. J. 42 (1986) 249-258.

[9] Christon R., Le Dividich J., Seve B., Aumaitre A., Effect of ambient temperature on the metabolic use of dietary energy and nitrogen in growing rat, Reprod. Nutr. Dev. 24 (1984) 327-341.

[10] Daghir N.J., Nutrition and Climatic stress, in: Proceedings of the XXth World Poultry Congress WPSA, New-Delhi, India, 2-5 September 1996. pp. 141-150.
[11] D'Mello J.P.F., Responses of growing poultry to amino acids, in: D'Mello J.P.F. (Ed.), Amino acids in farm animal nutrition, CAB International Wallingford (GBR), 1994, pp. 205-243.

[12] Garlick P.J., Mc Nurlan M.A., Preedy V.R., A rapid and convenient technique for measuring the rate of protein synthesis in tissues by injection of $\left[{ }^{3} \mathrm{H}\right]-$ Phe, Biochem. J. 192 (1980) 719-723.

[13] Geraert P.A., Métabolisme énergétique du poulet de chair en climat chaud, Inra Prod. Anim. 4 (1991) 257-267.

[14] Geraert P.A., Guillaumin S., Leclercq B., Are genetically lean broilers more resistant to hot climate?, Br. Poult. Sci. 34 (1993) 643-653.

[15] Geraert P.A., Padilha J.C.F., Guillaumin S., Metabolic and endocrine changes induced by chronic heat exposure in broiler chickens: growth performance, body composition and energy retention, Br. J. Nutr. 75 (1996) 195-204.

[16] Han Y., Baker D.H., Effects of sex, heat stress, body weight, and genetic strain on the dietary lysine requirement of broiler chicks, Poult. Sci. 72 (1993) 701-708.

[17] Howlider M.A.R., Rose S.P., Temperature and the growth of broilers, World's Poult. Sci. J. 43 (I987) 228-237.

[18] Howlider M.A.R., Rose S.P., Rearing temperature and the meat yield of broilers, $\mathrm{Br}$. Poult. Sci. 30 (1989) 61-67.

[19] Kruskal W.H., Wallis W.A., Use of ranks in one-criterion variance analysis, J. Am. Stat. Assoc. 47 (1952) 583-621.

[20] Kubena L.F., Deaton J.W., Reece F.N., May J.D., Vardaman T.H., The influence of temperature and sex on the amino acid requirements of the broiler, Poult. Sci. 5 I (1972) 1391-1396.

[21] Leeson S., Nutritional considerations of poultry during heat stress, World's Poult. Sci. J. 42 (1986) 69-81.

[22] McLeod M.G., Energy and nitrogen intake, expenditure and retention at $32{ }^{\circ} \mathrm{C}$ in growing fowl given diets with a wide range of energy and protein contents, Br. J. Nutr. 67 (1992) 195-206.

[23] Munro H.N., Fleck A., Analysis of tissues and body fluids for nitrogenous constituents, in: Munro H.D. (Ed.), Mammalian Protein Metabolism, Vol III, Academic Press, New York, 1969, pp. 424-525.

[24] Picard M., Sauveur B., Fenardji F., Angulo I., Mongin P., Ajustements technico-économiques possibles de l'alimentation des volailles dans les pays chauds, Inra Prod. Anim. 6 (1993) 87-103.

[25] Rinaldo D., Le Dividich J., Effects of warm exposure on adipose tissue and muscle metabolism in growing pigs, Comp. Biochem. Physiol. 100A (1991) 995-1002. 
[26] Smith P.K., Krohn R.I., Hermanson G.T., Mallia A.K., Gartner F.H., Provenzano M.D., Fujimoto E.K., Goeke N.M., Olson B.J., Klenk D.C., Measurement of protein using bicinchoninic acid, Anal. Biochem. 150 (1985) $76-85$.

[27] Tesseraud S., Maaa N., Peresson R., Chagneau A.M., Relative responses of protein turnover in three different skeletal muscles to dietary lysine deficiency in chicks, Br. Poult. Sci. 37 (1996) 641-650.

[28] Tesseraud S., Peresson R., Chagneau A.M., Agerelated changes of protein turnover in specific tissues of the chick, Poult. Sci. 75 (1996) $627-631$.

[29] Tesseraud S., Peresson R., Lopes J., Chagneau A.M., Dietary lysine deficiency greatly affects muscle and liver protein turnover in growing chickens, Br. J. Nutr. 75 (1996) 853-865.

[30] Waldroup P.W., Influence of environmental temperature on protein and amino acid needs of poultry, Fed. Proc. 41 (1982) 2821-2823.

[31] Waldroup P.W., Mitchell R.J., Payne J.R., Hazen K.R., Performance of chicks fed diets formulated to minimize excess levels of essential amino acids, Poult. Sci. 55 (1976) 243-253. 